\title{
Strates
}

STRATES Matériaux pour la recherche en sciences sociales

2| 1987

Mélanges

\section{L'emploi en France : Reclasser une base de données}

\section{Francine Goblet}

\section{(2) OpenEdition}

Journals

Édition électronique

URL : http://journals.openedition.org/strates/335

DOI : $10.4000 /$ strates.335

ISSN : $1777-5442$

Éditeur

Laboratoire Ladyss

Édition imprimée

Date de publication : 1 janvier 1987

ISSN : 0768-8067

\section{Référence électronique}

Francine Goblet, «L'emploi en France : Reclasser une base de données », Strates [En ligne], 2 | 1987,

mis en ligne le 08 décembre 2004, consulté le 08 septembre 2020. URL : http://

journals.openedition.org/strates/335; DOI : https://doi.org/10.4000/strates.335

Ce document a été généré automatiquement le 8 septembre 2020

Tous droits réservés 
L'emploi en France : Reclasser une base de données

Francine Goblet 